Review

\title{
Assessment and Evaluation of the Intake of Sugars in European Countries
}

\author{
Michiel R. H. Löwik
}

Citation: Löwik, M.R.H. Assessment and Evaluation of the Intake of Sugars in European Countries. Appl. Sci. 2021, 11, 11983. https://doi.org/ 10.3390/app112411983

Academic Editors: Philip Prinz and Wojciech Kolanowski

Received: 8 October 2021

Accepted: 2 December 2021

Published: 16 December 2021

Publisher's Note: MDPI stays neutral with regard to jurisdictional claims in published maps and institutional affiliations.

Copyright: (C) 2021 by the author. Licensee MDPI, Basel, Switzerland. This article is an open access article distributed under the terms and conditions of the Creative Commons Attribution (CC BY) license (https:/ / creativecommons.org/licenses/by/ $4.0 /)$.
Tzitzo, 3904 DM Veenendaal, The Netherlands; michiel.lowik@tzitzo.nu; Tel.: +31-318-555-014

\begin{abstract}
The intake of sugars is a trending topic in nutrition and health. For an evaluation of the sugar intake (comparison with existing guidelines), up-to-date information on the guidelines, dietary intake and trends in the intake is needed. The available information for European countries is presented in this review. The existing guidelines on the intake show that there is currently no consensus among the experts from different organizations. The differences are mainly due to the selection of the adverse health outcomes for which there is sufficient evidence. Data from national European surveys show that the mean proportion of energy coming from added sugars for most European population groups is below $10 \%$, and that the trend in the intake seems to be downwards. There are, however, many serious uncertainties and assumptions needed for the assessment of the intake of sugars. For instance, the assessment reflects a short period of the lives of the respondents, the data collection in several surveys was conducted more than 10 years ago, and recent reformulations of the industry are not considered in the food composition tables. Due to the uncertainties regarding the assessment of the sugar intake in Europe, the information should be used prudently and with care.
\end{abstract}

Keywords: dietary intake; sugar; dietary guidelines

\section{Introduction}

A reduction of the intake of sugars is a hot topic in relation to a decrease of energy intake to prevent body weight gain and accomplish weight loss among those with overweight or obesity. In population groups, several individuals have an intake of sugars that is not in line with the existing dietary guidelines. Basically, there are two strategies to reduce the intake of sugars: changing consumer behaviour, via nutritional education or other policy measures such as nutritional labelling, and product reformulation by the industry. A sugar-substitution strategy of the industry can be partial, total, or gradual for different product categories, such as soft drinks, bakery, and ice cream [1,2]. Additionally, decisions have to be made on the sugar substitutes that may be artificial sweeteners, stevia, or polyols, such as malitol, xylitol or sorbitol [3]. Polyols can act as sweeteners and bulking agents for confectionery products and replace saccharose on a one-to-one basis [4]. For instance, Nastaj et al. [5] showed that a significant reduction in the sugar content was possible, and that the reformulated product had the characteristic features of traditional meringue and lower caloric value.

In the scientific literature, there is a long-standing tradition to investigate the link between the intake of sugars and health and the results are reflected in dietary guidelines when sufficient evidence is available. Guidelines for a healthy diet are established by nutrition experts and several organizations have published (some on a regular basis) such guidelines. The World Health Organization (WHO) recommended in 2015 for the whole world a reduction of the intake of free sugars to $<10$ energy $\%$ (en $\%)$. This recommendation is based on the association of free sugars with dental caries [6]. The European Food Safety Authority (EFSA) is currently updating their scientific opinion of 2010 on sugars [7]. In 2010 the EFSA concluded that there was insufficient evidence to set an upper limit for sugars [8]. The United States (US) dietary guidelines are updated every five years; the 
latest version was published in 2020 [9]. The US guideline advises Americans to cut down somewhat, from an average intake of 13 to an intake of less than $10 \%$ of energy from added sugars. These three examples of guidelines show that the existing recommendations for the intake of sugars are not the same. Therefore, it is of interest to investigate what other guidelines recommend regarding the intake of sugars and to look at the reason of any differences in the recommendations. This is one of the aims of this study.

Guidelines can be formulated for total, free, and added sugars. Total sugars are all monosaccharides and disaccharides, present in food, irrespective of the source. In most cases, this is predominantly made up of sucrose, fructose, glucose, and lactose. Added sugars are mono- and disaccharides used as ingredients in processed and prepared foods and sugars eaten separately or added to foods at the table. Added sugars do not include sugars present in intact fruit or vegetables or milk, or in juiced or pureed fruit or vegetables. Free sugars are somewhat wider ranging than added sugars and are monoand disaccharides added to foods by the manufacturer, cook, or consumer plus sugars naturally present in honey, syrups, fruit juices and fruit juice concentrates. Sugars from intact fruit, vegetables, and milk do not belong to the free sugars.

Quantitative guidelines can be used as reference values for dietary intake figures. National surveys provide aggregate data from individuals of a country. Representative dietary intake data of the population in a country are useful for determining the foods, beverages, and nutrients consumed, assessing dietary adequacies and shortcomings, when compared to dietary guidelines, and for monitoring trends. Dietary intake data can be compared with dietary guidelines to obtain an impression about the quality of the intake; this data will be searched for, and presented, from national European surveys. In the past decades, many European countries collected dietary intake data on a national level. This article aims to provide an overview of these surveys with information on and an evaluation of the daily intake of total, free, and/or added sugars and discusses the possible trend in the intake of sugars.

\section{Methods}

Three sources $[7,10,11]$ were used to identify guidelines on the intake of sugars and only guidelines that applied to one or more European countries were included in this paper. Furthermore, PubMed and Google scholar were used to find guidelines published after the publication of these three papers using search terms such as "nutritional guidelines", "dietary guidelines", and "guidelines AND sugar". Additionally, national government websites were consulted to search for dietary guidelines.

For the intake data, PubMed and Google Scholar were searched for relevant studies with the following key words: sugar intake, sugar consumption, national dietary survey, and national food consumption survey. The references of the most recent publications were used to locate the original reports presenting the survey data. This was completed because these reports are often written in the national language and can be hard to locate for English speakers. Three review articles were used to find these surveys: Azais-Braesco et al. [12], Newens and Walton [13], and Walton et al. [14]. As a result of this method, this study is not a systematic review, but it is, however, possible to provide an overview of the surveys with information on the daily intake of total, free, and/or added sugars.

Several inclusion and exclusion criteria were used for the survey data: (1) only nationally representative surveys published from the year 2000 onwards were included; (2) only data on total, free, and added sugars were used; (3) because food frequency questionnaires (FFQs) are not quantitatively precise, and intake is often misreported, surveys based on data obtained with FFQs were excluded. Only intake assessed with food/diet recalls and 24-h recalls were included; (4) only data on the sugar intakes in energy $\%(\mathrm{en} \%)$ were included to adjust for differences in energy intake among population groups (especially age groups).

The intake data are presented for different population groups in line with the classification of the EFSA protocol [7]: 
- Infants $\geq 4$ to $<12$ months;

- $\quad$ Toddlers (young children) $\geq 1$ to $<3$ year;

- Children $\geq 3$ to $<10$ years;

- Adolescents $\geq 10$ to $<18$ years;

- $\quad$ Adults $\geq 18$ to $<65$ years;

- $\quad$ Elderly adults $\geq 65$ years.

The intake data will, whenever possible, be classified in these group separately for the genders.

\section{Results}

\subsection{Guidelines on Sugars}

There is overlap in the included guidelines in the reviews of Erickson et al. [11], Buyken et al. [10], and in the protocol of the EFSA [7]. All the guidelines, except one, presented in Table 1 are formulated for the general (healthy) population. The guideline for France [15] applies to adults. The various recommendations for sugars intake differ, as four of the nine reports did not quantify their recommendations, but simply encouraged limiting or reducing the intake of sugars in food and beverages [8,16-18]. The quantitative guidelines were formulated for added sugars (Nordic countries) [19], free sugars (WHO, United Kingdom (UK), Germany) [6,20,21], and total sugars (France) [15]. Free sugars should be less than $10 \%$ of total energy whilst the UK guideline for the mean of the population was $5 \%$ of total energy as free sugars. The EFSA [8] was among the organizations that were (in 2010) unable to set an upper limit for sugars intake. Currently, the EFSA is looking again at dietary sugars recommendations. The guidelines were based on various health concerns, including fasting triglycerides, dental caries, and weight gain. All guidelines originate from authoritative organizations. There is, however, no consensus among the scientists from different countries (and the WHO and the EFSA) [6,8].

The differences are partly due the in- and exclusion criteria for the original studies. Table 1 shows that the differences are mainly due to a different selection of the adverse health outcomes for which there is sufficient evidence.

\subsection{Intake of Total Sugars}

In total, twenty-six eligible surveys were found. For several European countries, data are missing due to the in- and exclusion criteria. The number of separate data on the intake of sugars is higher due to the inclusion of more than one age group in the survey and included data on total, free, and/or added sugars. In Tables S1 and S2 of the Annex the characteristics of the included surveys among children and adults with information on the intake of total, added, and/or free sugars are presented. For children, in total nineteen different surveys were identified. The number of age groups is larger because several surveys included more than one of the beforementioned age groups. Seven surveys were completed after 2015 [22-28], eight between 2010 and 2015 [29-36], three between 2005 and 2009 [37-39], and for one (Finland) the data are from 2003-2005 [40]. The most recent data are from 2018 (children in Ireland) [24]. For adults (including the elderly), in total, fourteen surveys were found. Three surveys completed the data collection after the year 2015 [22,28,41], nine in 2010-2015 [26,32,33,36,42-46], and two between 2005 and $2009[37,47]$.

The most recent data are from 2017 (Austria) [41]. In total, seventy-four data (mostly separately for boys and girls) on the intake of total/free/added sugars among children were obtained. Most (47) had a sample size below 250 subjects. For adults, 34 out of 78 the sample size was below 250 subjects. The range in the response rate among children was $23-75 \%$, and among adults $23-65 \%$. The survey from Portugal has the lowest response rate: $23 \%$ [48]. 
Table 1. Overview of the guidelines for the dietary intake of sugars that apply to European countries.

\begin{tabular}{|c|c|c|c|}
\hline Country & Guideline & Endpoints & Reference ** \\
\hline Europa & Insufficient data to set an upper limit & Several endpoints & EFSA, 2010 [8] \\
\hline France & $\begin{array}{l}<100 \mathrm{~g} \text { total sugars per day } \\
\text { (Excluding lactose and galactose } \\
\text { naturally present in milk and } \\
\text { dairy products) }\end{array}$ & Fasting triglycerides & ANSES, 2016 [15] \\
\hline Germany & Free sugars $<10$ en $\%$ & Adopted from $\mathrm{WHO}$ & $\begin{array}{c}\text { German Obesity Society (DAG), } \\
\text { German Diabetes Society (DDG) } \\
\text { and German Nutrition Society } \\
\text { (DGE), 2019 [21] }\end{array}$ \\
\hline Ireland & Avoid excessive sugar consumption & Unknown & FSAI, 2011 [16] \\
\hline Netherlands & Minimize SSB consumption & Weight gain, T2DM & HC, 2015 [17] \\
\hline Nordic Countries * & Added sugars < 10 en $\%$ & $\begin{array}{l}\text { T2DM, Weight gain, } \\
\text { Nutrient density, } \\
\text { Dental caries }\end{array}$ & NNR, 2012 [19] \\
\hline Spain & $\begin{array}{l}\text { Occasional consumption Sweets } \\
<4 \text { times per day }\end{array}$ & Dental caries & SSCN, 2001 [18] \\
\hline UK & $\begin{array}{l}\text { Mean population intake of free sugars } \\
5 \mathrm{en} \% \text {, SSB should be minimized }\end{array}$ & $\begin{array}{c}\text { Energy intake } \\
\text { SSB: T2DM, } \\
\text { Increase BMI (children) } \\
\text { Dental caries }\end{array}$ & SACN, 2015 [20] \\
\hline $\begin{array}{l}\text { World (including } \\
\text { Europe) }\end{array}$ & $\begin{array}{c}\text { Reduce intake of free sugars to }<10 \mathrm{en} \% \\
\text { Conditional: Reduce intake of free } \\
\text { sugars to } 5 \mathrm{en} \%\end{array}$ & Dental caries & WHO, 2015 [6] \\
\hline
\end{tabular}

${ }^{*}$ Denmark, Iceland, Finland, Norway, Finland, Norway, Sweden. ${ }^{* *}$ EFSA = European Food Safety Authority; GNS = German Nutrition Society; FSAI = Food Safety Authority of Ireland; HC = Health Council; NNR = Nordic Nutrition Recommendations; SSCN = Spanish Society of Community Nutrition; SACN = Scientific Advisory Committee on Nutrition; WHO = World Health Organization.

None of the surveys presented figures for total sugars (in en\%) among infants. A France survey reported a daily intake of 65.4 and $65.8 \mathrm{~g}$ total sugars for $0-11$ months old male and female infants, respectively. Among toddlers (1-3-year-olds), the mean $\%$ contribution of total sugars to the energy intake varied from 24.9 to 31.4 with the lowest values in Ireland and Italy, and the highest value in the Netherlands. Among the 3-9-year-old children, the mean en\% from total sugars ranged from 17.0 (Italy) to 28.6 (female children in The Netherlands). The mean en\% in Belgium and Portugal was just above 25, whereas the proportion of energy coming from total sugars in Ireland was 18.7. For adolescents in Belgium, the en \% for total sugars ranged from 21 to 25 , which is comparable with Germany (24-26 en\%) and The Netherlands (24-26 en\%). Norway had the lowest values: 11.9 and 12.8 en\% for males and females, respectively. The adolescents in Italy obtained almost 16\% of their energy from total sugars; in Spain this was $17-19 \%$, and in Ireland this was 20.4, which is about the same as for Portugal, with $20 \mathrm{en} \%$.

In Table S3 of the Annex the results of the intake of total sugars among adult population groups (except the elderly) are presented. The range in the intake is 13-26 energy $\%$. Most countries had a mean intake of total sugars below 20 en $\%$. Germany, Switzerland (women only), and the Netherlands (younger age groups) have a mean intake of total sugars of $20 \mathrm{en} \%$ or higher. The differences between the age groups are not consistent. Adult women tend to have a somewhat higher intake of total sugars than adult men. Among the elderly the range in the percentage of energy from total sugars is 13.3-20.6. The highest value is observed in the Netherlands and the lowest in Italy, which is in line with the findings among adults. The dietary intake of total sugars among elderly people varies between $15-20$ en $\%$ for Ireland, Portugal, and Spain. The differences between the genders, women having a higher intake, is more pronounced (mostly about 3 en\%) than for adults. The 
women in the Netherlands have an intake of total sugars that is $1.5 \mathrm{en} \%$ higher, and in Portugal this difference is $4.3 \mathrm{en} \%$.

\subsection{Intake of Free Sugars}

None of the surveys presented figures for free sugars among infants. Ireland (9.0, 11.0 and 13.4 for the toddlers of 1, 2 and 3 year of age), the Netherlands (15.6 among males and 17.4 among females), and the UK (11.3) reported the en $\%$ of free sugars among toddlers. Among 3-9-year-old children, the proportion of energy coming from free sugars was lowest in Portugal (9.1 for males and 9.6 for females) and Ireland (9.5), and highest in the Netherlands (19.0 for boys and 19.5 for girls). Among these children the UK has an intermediate position with 13.6 for boys and 13.4 for girls. For adolescents, data are available from Germany (about $16 \mathrm{en} \%$ ), Portugal (9-10 en\%), Spain (about $10 \mathrm{en} \%$ ), the Netherlands (16-18 en\%), and the UK (about 14 en\%).

In Table 2 the results of the intake of free sugars among adult population groups (except the elderly) are presented. The range in the mean intake of free sugars is 7-18 en\%. Austria has the highest mean intake with all the adult groups having a mean intake above $16 \mathrm{en} \%$. Other countries with a mean intake above $10 \mathrm{en} \%$ for free sugars are Germany, Switzerland, the Netherlands, and the UK. Spain, Portugal, and Ireland (except for 18-35-year-old women) have mean values for free sugars below $10 \mathrm{en} \%$. In most countries women have for free sugars a higher mean en\% than men. Among the adult population groups there is no clear association between the intake of free sugars and age in the three countries that presented intake values for different age groups. The standard deviations are relatively high, indicating that the distributions are skewed, probably to the right. Among elderly people the range of the intake of free sugars is $4.4-12.5 \mathrm{en} \%$. All four mean values for the UK are above $10 \mathrm{en} \%$. Ireland and the Netherlands have mean values between 8 and 10 en\%, whereas those for Portugal and Spain are between 4.4 and $6.2 \mathrm{en} \%$. Except for the UK, women obtain more energy from free sugars than men.

\subsection{Intake of Added Sugars}

Information on added sugar is available for infants in Denmark and Norway. In Denmark, the en\% increased in the first year. Among female infants of 6-7 months old, the mean intake of added sugars is $1.6 \mathrm{en} \%$ and at $10-11$ months the average is $3.2 \mathrm{en} \%$. For male infants, these figures are 2.1 and 4.1, respectively. In Norway infants of 7-11 months have a mean en $\%$ of added sugars of 4.0. The standard deviations were close to the mean values. For instance, in Norway the standard deviation was 4.1. Information on the mean intake of added sugars for toddlers was available for Denmark (range among the one- and two-year-olds is 5.9-9.0 en\%, with higher values for the older toddlers), Norway (6.7 en\%), and the Netherlands (the en \% were 12.7 for male and 14.1 for female toddles). Among 3-9-year-old children, the range in the proportion of energy coming from added sugars in Denmark, Ireland, and Portugal was small (8.5-11.2 en\%). The Netherlands, with a mean en $\%$ of about $17 \%$, is a clear exception. The mean energy obtained from added sugars among adolescents was in Denmark, at 11-12 en\%, which is about the same for adolescents in Germany (12 en \%) and Ireland (12 en \%). Norway with estimates of almost $9 \mathrm{en} \%$ and Portugal with an intake just over $9 \mathrm{en} \%$ have somewhat lower values.

In Table 3 the results of the intake of added sugars among adult population groups (except the elderly) are presented. The range in the mean intake of added sugars is 6-13 en\%. Thirty-two out of the thirty-eight adult population groups have an average intake of added sugars of $10 \mathrm{en} \%$ or lower. In general adult women have a higher intake of added sugars (en\%) than adult men, and the mean intake is lower for the older age groups. The largest difference is observed among the men in the Netherlands: $13 \mathrm{en} \%$ for 19-30-year-old and $8.9 \mathrm{en} \%$ for those 51-70 years of age. The standard deviations are relatively, in comparison with the mean values, large. Among the elderly the range in the mean dietary intake of added sugars is $6.3-8.5$ en \% for Denmark, Hungary, Ireland, Norway, and the Netherlands. Portugal has a lower mean energy $\%$ for added sugars: 
4.0 for men and 5.2 for women. The mean intake of added sugars (en\%) among elderly women tends to be higher than for elderly men.

Table 2. The dietary intake of free sugars (energy\%) among adult Europeans.

\begin{tabular}{|c|c|c|c|}
\hline Country & Gender & Age Group (Years) & Mean \pm SD \\
\hline \multirow[t]{6}{*}{ Austria [41] } & Male & $19-24$ & $16.4 \pm 8.1$ \\
\hline & & $25-50$ & $16.4 \pm 7.4$ \\
\hline & & $51-64$ & $16.8 \pm 7.0$ \\
\hline & Female & $19-24$ & $16.8 \pm 7.6$ \\
\hline & & $25-50$ & $17.5 \pm 7.0$ \\
\hline & & $51-64$ & $18.1 \pm 6.8$ \\
\hline \multirow[t]{2}{*}{ Germany [47] } & Male & $15-80$ & 13.0 \\
\hline & Female & $15-80$ & 14.0 \\
\hline \multirow[t]{6}{*}{ Ireland [43] } & Male & $18-35$ & $9.2 \pm 4.7$ \\
\hline & & $36-50$ & $8.2 \pm 4.3$ \\
\hline & & $51-64$ & $7.9 \pm 4.2$ \\
\hline & Female & $18-35$ & $10.2 \pm 4.9$ \\
\hline & & $36-50$ & $8.3 \pm 4.3$ \\
\hline & & $51-64$ & $8.1 \pm 4.3$ \\
\hline \multirow[t]{2}{*}{ Portugal [26] } & Male & $18-64$ & 6.9 \\
\hline & Female & $18-64$ & 7.9 \\
\hline \multirow[t]{2}{*}{ Spain [36] } & Male & $18-64$ & $7.0 \pm 4.8$ \\
\hline & Female & $18-64$ & $7.3 \pm 4.5$ \\
\hline \multirow[t]{2}{*}{ Switzerland [46] } & Male & $18-75$ & 11.4 \\
\hline & Female & $18-75$ & 11.5 \\
\hline \multirow[t]{6}{*}{ The Netherlands [22] } & Male & $19-30$ & 14.6 \\
\hline & & $31-50$ & 12.0 \\
\hline & & $51-70$ & 10.1 \\
\hline & Female & 19-30 & 13.9 \\
\hline & & $31-50$ & 11.8 \\
\hline & & $51-70$ & 10.4 \\
\hline \multirow[t]{2}{*}{ United Kingdom [28] } & Male & $19-64$ & $11.1 \pm 6.4$ \\
\hline & Female & $19-64$ & $11.2 \pm 6.1$ \\
\hline
\end{tabular}


Table 3. The dietary intake of added sugars (energy\%) among adult Europeans.

\begin{tabular}{|c|c|c|c|}
\hline Countr.y & Gender & Age Group (Years) & Mean \pm SD \\
\hline \multirow[t]{10}{*}{ Denmark [33] } & Male & $18-24$ & $10.0 \pm 6.5$ \\
\hline & & $25-34$ & $10.0 \pm 5.7$ \\
\hline & & $35-44$ & $9.0 \pm 5.7$ \\
\hline & & $45-54$ & $7.0 \pm 4.9$ \\
\hline & & $55-64$ & $7.0 \pm 4.7$ \\
\hline & Female & $18-24$ & $11.0 \pm 6.9$ \\
\hline & & $25-34$ & $9.0 \pm 4.8$ \\
\hline & & $35-44$ & $9.0 \pm 5.3$ \\
\hline & & $45-54$ & $8.0 \pm 5.0$ \\
\hline & & $55-64$ & $7.0 \pm 3.6$ \\
\hline \multirow[t]{4}{*}{ Hungary [42] } & Male & $18-34$ & 9.3 \\
\hline & & $35-64$ & 7.3 \\
\hline & Female & $18-34$ & 11.3 \\
\hline & & $35-64$ & 8.0 \\
\hline \multirow[t]{6}{*}{ Ireland [43] } & Male & $18-35$ & $8.1 \pm 4.3$ \\
\hline & & $36-50$ & $7.5 \pm 4.1$ \\
\hline & & $51-64$ & $7.1 \pm 4.0$ \\
\hline & Female & $18-35$ & $9.2 \pm 4.7$ \\
\hline & & $36-50$ & $7.5 \pm 4.1$ \\
\hline & & $51-64$ & $7.4 \pm 4.1$ \\
\hline \multirow[t]{8}{*}{ Norway [45] } & Male & $18-29$ & $9.2 \pm 6.9$ \\
\hline & & $30-39$ & $7.2 \pm 6.0$ \\
\hline & & $40-49$ & $7.7 \pm 6.0$ \\
\hline & & $50-59$ & $6.3 \pm 5.1$ \\
\hline & Female & $18-29$ & $9.3 \pm 6.5$ \\
\hline & & $30-39$ & $8.2 \pm 5.6$ \\
\hline & & $40-49$ & $6.6 \pm 4.4$ \\
\hline & & $50-59$ & $6.8 \pm 4.9$ \\
\hline \multirow[t]{2}{*}{ Portugal [26] } & Male & $18-64$ & 6.5 \\
\hline & Female & $18-64$ & 7.1 \\
\hline \multirow[t]{2}{*}{ Switzerland [46] } & Male & $18-75$ & 9.4 \\
\hline & Female & $18-75$ & 9.3 \\
\hline \multirow[t]{6}{*}{ The Netherlands [22] } & Male & $19-30$ & 13.0 \\
\hline & & $31-50$ & 10.6 \\
\hline & & $51-70$ & 8.9 \\
\hline & Female & $19-30$ & 12.3 \\
\hline & & $31-50$ & 10.4 \\
\hline & & $51-70$ & 9.1 \\
\hline
\end{tabular}

\section{Discussion}

The results on the guidelines on sugars that apply to Europe show that there is no consensus among scientific experts due to differences in the (quantitative) recommendation 
on total, added, or free sugars and the chosen endpoint. Total sugars include sugars from fruit, vegetables, and dairy products, which are important sources of essential nutrients. From a public health perspective, a piece of advice to reduce the intake of total sugars can be counterproductive, despite that all fermentable carbohydrates can influence dental caries. Free sugars include added sugars plus sugars naturally present in honey, syrups, fruit juices, and fruit juice concentrates. Next to added sugars is fruit juice, the most important source of free sugars. Kahn and Sievenpiper [49] concluded in their review that $100 \%$ pure fruit juice has not shown reliable associations with diabetes or cardiometabolic diseases. From a health perspective, it is advised to focus on added sugars. The results show that most population groups have a mean intake of added sugars below $10 \mathrm{en} \%$.

For information on trends, the review of Wittekind and Walton [50] and data from the Netherlands (with detailed information about the trends in added sugars) were used. The study of Wittekind and Walton [50] concluded that findings indicate that in most population comparisons, estimated dietary sugars intake is either stable or decreasing in both absolute (gram/day:g/d) and relative (en\%) terms. A more recent comparison (2007-2010 versus 2012-2016) for the Netherlands confirms this downward trend in the intake of sugars [51]. The mean intake of added sugar among 7-79-year-old individuals was 18\% lower in 2012-2016 than in 2007-2010. The average consumption of sugars-containing non-alcoholic drinks was $16 \mathrm{~g} /$ day and of sugar \& sweets was $3 \mathrm{~g} /$ day $(10 \%)$, and was significantly lower in the survey of 2012-2016. A significant decrease was also seen within the last Dutch survey among adults. In the years 2012-2014, the mean consumption of sugar-containing drinks was $312 \mathrm{~g} /$ day and in 2015-2016 the mean consumption was $262 \mathrm{~g} /$ day. This is a decrease of $49 \mathrm{~g} /$ day (corresponding with 16\%). According to Ter Borg et al. [52], Dutch adults consumed $7.5 \mathrm{~g} / \mathrm{d}$ less sugar (about thirty calories) because of the so-called prevention agreement to reduce the amount of (added) sugars in food products.

The range in the years of data collection of the included surveys is 2003-2018. The most recent data on children is from Ireland (2018) and, on adults, from Austria (2017). The minority of the surveys completed the data collection in 2016 or later. So, many data are (somewhat) old and will not be representative of the actual situation. Most data presented on total, free and/or added sugars are probably outdated. The data on the trends show that the current intake is probably lower than the figures presented in this paper. According to the systematic review of Della Corte et al. [53], consumption among US children and adolescents increased substantially in the decades preceding 2000, followed by a faster and continued decline of the intake of sugar-sweetened beverages and dietary sugars. Other international intake trends did not reveal drastic increases and decreases in sugars (from sugar-sweetened beverages). In this review eight out of fifteen studies were from Europe.

All dietary intake methodologies are, to some extent, imperfect due to limitations. For instance, there may be incomplete reporting by subjects that do not remember the consumption of specific foods or beverages, foods consumed that are not recorded when keeping records, biased sampling, and inaccurately measuring or estimations of (standard) portion sizes. There are many uncertainties in the resulta of food consumption surveys. The most relevant uncertainties for this review are discussed hereafter. For an overview of the critical uncertainties in food consumption surveys, see Kroes et al. [54]. The uncertainties can be large, especially for (high and low) percentile values. That is the reason that only mean values are presented, since these are less prone to bias. In contrast to total sugars (that can be analyzed), the content of free and added sugars is not readily available in most food composition databases. To estimate the content of added sugars, a ten-step approach is available [55], and according to the authors the last four last steps are subjective.

The surveys are nationwide, but this no guarantee for the representativeness of the samples. A small sample size and small number of recording days contribute to a sampling error and thereby sampling uncertainty [56]. In this paper 152 different population groups are presented with data on the intake of total, free, and/or added sugars and 81 have a sample size below 250 respondents. A smaller sample size introduces more uncertainty about the estimates. Another type of sampling uncertainty is selection bias. This can 
be unintentionally due to response bias, especially when the response rate is low, and intentionally by excluding population groups such as sick people and non-native-language speaking subjects. The range in the response rate is $23-75 \%$. The lower the response rate, the more likely that a response bias exists. The survey with the lowest response $(23 \%)$ was from Portugal.

Food composition tables are needed to estimate the intake of sugars. There is a broad range of foods containing sugars with varying quantities in different food products, both solid and liquid. Food consumption surveys cannot incorporate all the food products that are available in the marketplace whereby the data of the surveys are incomplete regarding the food products and thereby the intake of sugars. Due to the limited number of food products included in the food composition tables, the estimates of the intake of sugars are crude figures. For instance, the over 28,000 codes in a Dutch food consumption survey that is included in this paper were linked to 1599 codes of the Dutch food composition table. This means that the assessment of the intake of sugars is based on broad categories rather than single foods, and information (on the variability) is lost in the exposure assessment. Other uncertainties regarding the sugar content are processing, recipes, food conversion factors, brands, and market share. The industry in many European countries is reformulating their products in that the sugar-containing products, especially sugar-sweetened beverages, have now a lower sugar content than in the food composition tables used in the studies. By definition, food composition data lag in the reality since an update takes time and can only be completed when the sugar content has actually changed. Therefore, the intake data presented are somewhat outdated.

All dietary methods are vulnerable to over- and under-reporting. For sugars, with guidelines to reduce the dietary intake, underreporting is more likely than overreporting. Food items with a negative health image (e.g., cakes, sweets, confectionery) are more likely to be under-reported. According to Kroes et al. [54] there are several possible reasons for underreporting: lower consumption during the data-collection period, consuming or reporting smaller portions than normal, or not all consumed food items are reported. Women are more likely to under-report than men, and under-reporting is more common among overweight and obese individuals. Other associated characteristics, for which there is less consistent evidence, include age, smoking habits, level of education, social class, physical activity, and dietary restraint [57].

Most data on the intake of sugars are based on 2-4 days ( 7 days at the most), which is not a good reflection of the chronic intake of an individual. Chronic diseases do not develop overnight but during many years, and for a link between diet and a chronic disease the information on the habitual dietary intake is needed. Souverein et al. [58] studied four methods to estimate the usual intake distribution from two 24-hour dietary recalls and found that the bias in the mean and the variation in the bias increases with a smaller sample size, higher variance ratios, and with more pronounced departures (skewness) from a normal distribution. Often, a large standard deviation (sometimes higher than the mean) is reported, which indicates a skewed (probably to the right) distribution whereby the mean value is in those cases (much) higher than the median value.

\section{Conclusions}

\section{Guidelines}

There is currently no scientific consensus on the guidelines regarding the intake of sugars.

Intake

Most population groups have an intake of added sugars below $10 \mathrm{en} \%$.

This conclusion should be used with care, since many estimates are not up to date and are affected by many critical uncertainties.

Trend

There are indications that the trend in the consumption of sugars is downward. 
Supplementary Materials: The following are available online at https: / www.mdpi.com/article/ 10.3390/app112411983/s1, Table S1. Characteristics of the included surveys among children with information on the intake of total, added, and/or free sugars for different age groups; Table S2. Characteristics of the included surveys among adults with information on the intake of total, added, and/or free sugars for different age groups; Table S3. The dietary intake of total sugars (energy\%) among adult Europeans.

Funding: This research was funded by Knowledge Centre sugar and nutrition.

Institutional Review Board Statement: Not applicable. This study did not involve humans or animals. Only published results are used.

Informed Consent Statement: Not applicable. This study did not involve humans. Only published results are used.

Data Availability Statement: Data are obtained from the literature and from open source official websites.

Conflicts of Interest: The author declares no conflict of interest. The funders had no role in the design of the study, in the collection, analyses, or interpretation of data, in the writing of the manuscript, or in the decision to publish the results.

\section{References}

1. Di Monaco, R.; Miele, N.A.; Cabisidan, E.K.; Cavella, S. Strategies to reduce sugars in food. Curr. Opin. Food Sci. 2018, 19, 92-97. [CrossRef]

2. Deliza, R.; Lima, M.F.; Ares, G. Rethinking sugar reduction in processed foods. Curr. Opin. Food Sci. 2021, 40, 58-66. [CrossRef]

3. Rice, T.; Zannini, E.K.; Arendt, E.; Coffey, A. A review of polyols-biotechnological production, food applications, regulation, labeling and health effects. Crit. Rev. Food Sci. Nutr. 2020, 60, 2034-2051. [CrossRef] [PubMed]

4. Nastaj, M.; Sołowiej, B.; Terpiłowski, K.; Mleko, S. Effect of erythritol on physicochemical properties of reformulated high protein meringues obtained from whey protein isolate. Int. Dairy J. 2020, 105, 104672. [CrossRef]

5. Nastaj, M.; Mleko, S.; Terpiłowski, K.; Tomczyńska-Mleko, M. Effect of Sucrose on Physicochemical Properties of High-Protein Meringues Obtained from Whey Protein Isolate. Appl. Sci. 2021, 11, 4764. [CrossRef]

6. World Health Organization. World Health Organization Guideline: Sugars Intake for Adults and Children; WHO: Geneva, Switzerland, 2015.

7. European Food Safety Authority. Protocol for the scientific opinion on the Tolerable Upper Intake Level of dietary sugars. EFSA J. 2018, 16, e05393.

8. European Food Safety Authority. European Food Safety Authority, Scientific Opinion on Dietary Reference Values for carbohydrates and dietary fibre. EFSA Panel on Dietetic Products, Nutrition, and Allergies. EFSA J. 2010, 8, 1462.

9. U.S. Department of Agriculture. Dietary Guidelines for Americans, 2020-2025; USDA and US DHHS: Washington, DC, USA, 2020.

10. Buyken, A.E.; Mela, D.J.; Dussort, P.; Johnson, I.T.; Macdonald, I.; Stowell, J.D.; Brouns, F.J.P.H. Dietary carbohydrates: A review of international recommendations and the methods used to derive them. Eur. J. Clin. Nutr. 2018, 72, 1625-1643. [CrossRef] [PubMed]

11. Erickson, J.; Sadeghirad, B.; Lytvyn, L.; Slavin, J.; Johnston, B.C. The Scientific Basis of Guideline Recommendations on Sugar Intake: A Systematic Review. Ann. Intern. Med. 2017, 166, 257-267. [CrossRef] [PubMed]

12. Azais-Braesco, V.; Sluik, D.; Maillot, M.; Kok, F.; Moreno, L.A. A review of total \& added sugar intakes and dietary sources in Europe. Nutr. J. 2017, 16, 6. [PubMed]

13. Newens, K.J.; Walton, J. A review of sugar consumption from nationally representative dietary surveys across the world. J. Hum. Nutr. Diet. 2016, 29, 225-240. [CrossRef]

14. Walton, J.; Bell, H.; Re, R.; Nugent, A.P. Current perspectives on global sugars consumption: Definitions, recommendations, population intakes, challenges and future direction. Nutr. Res. Rev. 2021, 2021, 1-62. [CrossRef] [PubMed]

15. Tappy, L.; Morio, B.; Azzout-Marniche, D.; Champ, M.; Gerber, M.; Houdart, S.; Mas, E.; Rizkalla, S.; Slama, G.; Mariotti, F.; et al. French Recommendations for Sugar Intake in Adults: A Novel Approach Chosen by ANSES. Nutrients 2018, 10, 989. [CrossRef]

16. Food Safety Authority of Ireland. Scientific Recommendations for Healthy Eating Guidelines in Ireland. 2011. Available online: https: / www.lenus.ie/handle/10147/216750 (accessed on 12 August 2021).

17. Kromhout, D.; Spaaij, C.J.K.; De Goede, J.; Weggemans, R.M. The 2015 Dutch food-based dietary guidelines. Eur. J. Clin. Nutr. 2016, 70, 869-878. [CrossRef] [PubMed]

18. Serra-Majem, L.; Aranceta, J. Nutritional objectives for the Spanish population. Consensus from the Spanish Society of Community Nutrition. Public Health Nutr. 2001, 4, 1409-1413. [CrossRef]

19. Nordic Council of Ministers. Nordic Nutrition Recommendations 2012: Integrating Nutrition and Physical Activity. Report No.: 9289326700. 2014. Available online: https://norden.diva-portal.org/smash/get/diva2:704251/FULLTEXT01.pdf (accessed on 12 August 2021). 
20. Public Health England. Scientific Advisory Committee on Nutrition: Carbohydrates and Health Report. 2015. Available online: https://www.gov.uk/government/publications/sacn-carbohydrates-and-health-report (accessed on 12 August 2021).

21. Ernst, J.B.; Arens-Azevêdo, U.; Bitzer, B.; Bosy-Westphal, A.; de Zwaan, M.; Egert, S.; Fritsche, A.; Gerlach, S.; Hauner, H.; Heseker, H. Quantitative Empfehlung zur Zuckerzufuhr in Deutschland. 2018. Available online: https://www.dge.de/fileadmin/public/ doc/ws/stellungnahme/Konsensuspapier_Zucker_DAG_DDG_DGE_2018.pdf (accessed on 12 August 2021).

22. Van Rossum, C.; Buurma-Rethans, E.; Dinnissen, C.; Beukers, M.; Brants, H.; Ocké, M. The Diet of the Dutch: Results of the Dutch National Food Consumption Survey 2012-2016. 2020. Available online: https://rivm.openrepository.com/handle/10029/624455 (accessed on 12 August 2021).

23. Bates, B.; Lennox, A.; Prentice, A.; Bates, C.; Page, P.; Nicholson, S.; Swan, G. National Diet and Nutrition Survey Results from Years 1, 2, 3 and 4 (Combined) of the Rolling Programme (2008/2009-2011/2012); Food Standards Agency: London, UK, 2014.

24. Irish Universities Nutrition Alliance. National Children's Food Survey II. 2019. Available online: https://irp-cdn.multiscreensite. com/46a7ad27 / files/uploaded/The\%20National\%20Children \%27s\%20Food\%20Survey \%20II\%20Summary\%20Report\%20-\% 20September\%202019.pdf (accessed on 12 August 2021).

25. FHI. UNGKOST 3 Landsomfattende Kostholdsundersøkelse Blant 4-åringer i Norge, 2016. 2016. Available online: https: / / www.fhi.no/globalassets / dokumenterfiler/rapporter/2016/rapport-ungkost-3-landsomfattende-kostholdsundersokelseblant-4-aringer-i-norge-2016.pdf (accessed on 12 August 2021).

26. IAN-AF. National Food and Physical Activity Survey (IAN-AF) 2015-2016. ANEXO 2-INGESTÃO NUTRICIONAL 2017. 2017. Available online: https://ian-af.up.pt/sites/default/files/IAN-AF\%20Relat\%C3\%B3rio\%20Resultados_0.pdf (accessed on 12 August 2021).

27. Perrar, I.; Schadow, A.M.; Schmitting, S.; Buyken, A.E.; Alexy, U. Time and Age Trends in Free Sugar Intake from Food Groups among Children and Adolescents between 1985 and 2016. Nutrients 2020, 12, 20. [CrossRef] [PubMed]

28. Roberts, C.; Steer, T.; Maplethorpe, N.; Cox, L.; Meadows, S.; Nicholson, S.; Page, P.; Swan, G. National Diet and Nutrition Survey: Results from Years 7 and 8 (Combined) of the Rolling Programme (2014/2015-2015/2016). 2018. Available online: https:/ /assets.publishing.service.gov.uk/government/uploads/system/uploads/attachment_data/file/699241/NDNS_ results_years_7_and_8.pdf (accessed on 12 August 2021).

29. Trolle, E.; Gondolf, U.H.; Ege, M.; Kørup, K.; Ygil, K.H.; Christensen, T. Danskernes Kostvaner: Spæd-og Småbørn 2006-2007; Report No.: 8792763987. 2013. Available online: https://orbit.dtu.dk/en/publications/danskernes-kostvaner-sp\%C3\%A6d-ogsm\%C3\%A5b\%C3\%B8rn-2006-2007 (accessed on 12 August 2021).

30. Helsedirektoratet. Spedkost-12 Måneder 2006-2007. 2009. Available online: https://www.helsedirektoratet.no/rapporter/ spedkost-og-smabarnskost-landsomfattende-kostholdsundersokelser/Spedkost $\% 2012 \% 20 \mathrm{~m} \%$ C3\%A5neder $\% 20 \%$ E2\%80\% 93\%20landsomfattende\%20kostholdunders\%C3\%B8kelse\%202007-2008.pdf/_/attachment/inline/1544ff4a-db55-4db1-b2 4b-f3efa19dd26b:20d97036e4aa5f5c92b672b5d6252256dc11da2b/Spedkost\%2012\%20m\%C3\%A5neder\%20\%E2\%80\%93\%2 0landsomfattende\%20kostholdunders\%C3\%B8kelse\%202007-2008.pdf (accessed on 12 August 2021).

31. Irish Universities Nutrition Alliance. National Pre-School Nutrition Survey 2010-11. 2012. Available online: https: / / irp-cdn.multiscreensite.com/46a7ad27/files/uploaded/The\%20National\%20Pre-School\%20Nutrition\%20Survey\%20 Summary\%20Report\%20June\%202012.pdf (accessed on 12 August 2021).

32. De Ridder, K. La Consommation Alimentaire. 2014. Available online: https:/ fcs.wiv-isp.be/nl/Gedeelde\%20\%20documenten/ FRANS/Rapport\%204/Chapter1_FR_finaal.pdf (accessed on 12 August 2021).

33. Pedersen, A.N.; Christensen, T.; Matthiessen, J.; Knudsen, V.K.; Sørensen, M.R.; Biltoft-Jensen, A.P.; Saxholt, E.; Danskernes Kostvaner 2011-2013: DTU Fødevareinstituttet, Danmarks Tekniske Universitet. Report No.: 8793109393. 2015. Available online: http:/ / www.food.dtu.dk/-/ media/Institutter/Foedevareinstituttet/Publikationer/Pub-2015/Rapport_DanskernesKostvaner-2011-2013.ashx?la=da (accessed on 12 August 2021).

34. Gunnarsdottir, I.; Helgadottir, H.; Thorisdottir, B.; Thorsdottir, I. Diet of six-year-old Icelandic children-National dietary survey 2011-2012. Laeknabladid 2013, 99, 17-23. [PubMed]

35. FHI. UNGKOST 3 Landsomfattende KostholdsundersøKelse Blant Elever i 4.-og 8. Klasse i Norge. 2015. Available online: https:/ / www.fhi.no/globalassets/dokumenterfiler/rapporter/2016/ungkost-rapport-24.06.16.pdf (accessed on 12 August 2021).

36. FEN. Ingesta, Perfil y Fuentes de Energía en la Población Española: Resultados Obtenidos del Estudio Científico ANIBES. 2013. Available online: https://www.fen.org.es/anibes/es/ingesta_perfil_y_fuentes_de_energia (accessed on 12 August 2021).

37. Sette, S.; Le Donne, C.; Piccinelli, R.; Arcella, D.; Turrini, A.; Leclercq, C. The third Italian National Food Consumption Survey, INRAN-SCAI 2005-06-Part 1: Nutrient intakes in Italy. Nutr. Metab. Cardiovasc. Dis. 2011, 21, 922-932. [CrossRef] [PubMed]

38. Helsedirektoratet. Småbarnskost—2 år Landsomfattende Kostholdsundersøkelse Blant 2 år Gamle Barn. 2009. Available online: https: / / www.helsedirektoratet.no/rapporter/spedkost-og-smabarnskost-landsomfattende-kostholdsundersokelser/Sm\%C3 \%A5barnskost $\% 202007 \% 20 \%$ E2\%80\%93\%20landsomfattende $\% 20$ kostholdsunders $\%$ C3\%B8kelse $\% 20$ blant $\% 202 \% 20 \%$ C3\%A5 r\%20gamle\%20barn.pdf/_/attachment/inline/54fa23d7-f5cc-4ce8-bc21-41418c21a126:5dee89c23943f83c1a8b2abbd0f7406641 30e983/Sm\%C3\%A5barnskost $\% 202007 \% 20 \%$ E2\%80\%93\%20landsomfattende $\% 20$ kostholdsunders $\%$ C3\%B 8 kelse $\% 20 \mathrm{blant} \% 20$ 2\%20\%C3\%A5r\%20gamle\%20barn.pdf (accessed on 12 August 2021).

39. Irish Universities Nutrition Alliance. The National Teens' Food Survey II (NTFS II). 2006. Available online: https://irp-cdn. multiscreensite.com/46a7ad27 / files / uploaded/The\%20National\%20Teens \%27\%20Food\%20Survey\%20\%282005-2006\%29.pdf (accessed on 12 August 2021). 
40. Kyttälä, P.; Ovaskainen, M.; Kronberg-Kippilä, C.; Erkkola, M.; Tapanainen, H.; Tuokkola, J.; Veijola, R.; Simell, O.; Knip, M.; Virtanen, S.M. Lapsen Ruokavalio Ennen Kouluikää. 2008. Available online: https://www.julkari.fi/handle/10024/78163 (accessed on 12 August 2021).

41. Rust P HVK. Österreichischer Ernährungsbericht 2017. 2017. Available online: https://broschuerenservice.sozialministerium.at/ Home/Download?publicationId=528 (accessed on 12 August 2021).

42. Sarkadi Nagy, E.; Bakacs, M.; Illés, É.; Nagy, B.; Varga, A.; Kis, O.; Schreiberné Molnár, E.; Martos, É. Országos Táplálkozás és Tápláltsági Âllapot Vizsgálat-OTÁP2014. II. A magyar lakosság energia-és makrotápanyag-bevitele. Orvosi Hetilap 2017, 158, 587-597. [CrossRef] [PubMed]

43. Walton, J.; Kehoe, L.; McNulty, B.; Nugent, A.; Flynn, A. Intakes and sources of dietary sugars in a representative sample of Irish adults (18-90 y). Proc. Nutr. Soc. 2017, 76. [CrossRef]

44. Barzda, A.; Bartkevičiūtè, R.; Baltušytè, I.; Stukas, R.; Bartkevičiūtè, S. Suaugusiu ir pagyvenusių Lietuvos gyventoju faktinès mitybos ir mitybos ipročiu tyrimas. Visuomenès Sveik. 2016, 1, 85-94.

45. Helsedirektoratet. Norkost 3 En Landsomfattende Kostholdsundersøkelse Blant Menn og Kvinner i Norge i Alderen 18-70 år, 201011. 2012. Available online: https:/ / www.helsedirektoratet.no/rapporter/norkost-3-en-landsomfattende-kostholdsundersokelseblant-menn-og-kvinner-i-norge-i-alderen-18-70-ar-2010-11/Norkost $\% 203 \% 20$ en $\% 201$ landsomfattende $\% 20 \mathrm{kostholdsundersokelse} \%$ 20blant $\% 20$ menn $\% 20$ og\%20kvinner\%20i\%20Norge\%20i\%20alderen-18-70\%20\%C3\%A5r\%202010-11.pdf/_/attachment/ inline/b7bafaab-6059-4450-8d76-c3ed9f3eaf3f:be251cd1153cf1ae8e4c46eedddc13b36da3d11d/Norkost\%203\%20en\%20 landsomfattende \%20kostholdsundersokelse \%20blant $\% 20$ menn $\% 20$ og $\% 20 \mathrm{kvinner} \% 20 \mathrm{i} \% 20 \mathrm{Norge} \% 20 \mathrm{i} \% 20$ alderen-18-70\% 20\%C3\%A5r\%202010-11.pdf (accessed on 12 August 2021).

46. Chatelan, A.; Gaillard, P.; Kruseman, M.; Keller, A. Total, Added, and Free Sugar Consumption and Adherence to Guidelines in Switzerland: Results from the First National Nutrition Survey menuCH. Nutrients 2019, 11, 1117. [CrossRef]

47. Teil, E. Nationale Verzehrsstudie II. Max Rubner-Institut, Editor Bundesforschungsinstitut für Ernährung und Lebensmittel. 2008. Available online: https://link.springer.com/article/10.1007/s12082-008-0148-1 (accessed on 12 August 2021).

48. Lopes, C.; Torres, D.; Oliveira, A.; Severo, M.; Guiomar, S.; Alarcão, V.; Vilela, S.; Ramos, E.; Rodrigues, S.; Oliveira, L.; et al. National Food, Nutrition and Physical Activity Survey of the Portuguese general population. EFSA Support. Publ. 2017, 14, 1341E. [CrossRef]

49. Khan, T.A.; Sievenpiper, J.L. Controversies about sugars: Results from systematic reviews and meta-analyses on obesity, cardiometabolic disease and diabetes. Eur. J. Nutr. 2016, 55, 25-43. [CrossRef]

50. Wittekind, A.; Walton, J. Worldwide trends in dietary sugars intake. Nutr. Res. Rev. 2014, 27, 330-345. [CrossRef] [PubMed]

51. Rijksinstituut voor Volksgezondheid en Milieu. Suiker, Toegevoegd. Available online: https://www.wateetnederland.nl/ onderwerpen/suiker (accessed on 12 August 2021).

52. ter Borg, S.; Beukers, M.; Brants, H.; Milder, I.; Wilson-van den Hooven, E. Het Geschatte Effect van het Akkoord Verbetering Productsamenstelling op de Dagelijkse zout-en Suikerinname in Nederland. Eindrapportage 2014-2020; RIVM: Bilthoven, The Netherlands, 2021.

53. Della Corte, K.; Fife, J.; Gardner, A.; Murphy, B.L.; Kleis, L.; Della Corte, D.; Schwingshackl, L.; LeCheminant, J.D.; Buyken, A.E. World trends in sugar-sweetened beverage and dietary sugar intakes in children and adolescents: A systematic review. Nutr. Rev. 2021, 79, 274-288. [CrossRef] [PubMed]

54. Kroes, R.; Müller, D.; Lambe, J.; Löwik, M.; van Klaveren, J.; Kleiner, J.; Massey, R.; Mayer, S.; Urieta, I.; Verger, P.; et al. Assessment of intake from the diet. Food Chem. Toxicol. 2002, 40, 327-385. [CrossRef]

55. Louie, J.C.Y.; Moshtaghian, H.; Boylan, S.; Flood, V.M.; Rangan, A.M.; Barclay, A.W.; Brand-Miller, J.; Gill, T.P. A systematic methodology to estimate added sugar content of foods. Eur. J. Clin. Nutr. 2015, 69, 154-161. [CrossRef] [PubMed]

56. Van Ooijen, H.; van der Voet, H.; Bakker, M.I. Identification and Handling of Uncertainties in Dietary Exposure Assessment; RIVM rapport 320103004; National Institute for Public Health and the Environment: Bilthoven, The Netherlands, 2009.

57. MacDiarmid, J.; Blundell, J. Assessing dietary intake: Who, what and why of under-reporting. Nutr. Res. Rev. 1998, 11, $231-253$. [CrossRef]

58. Souverein, O.W.; on behalf of the EFCOVAL Consortium; Dekkers, A.L.; Geelen, A.; Haubrock, J.; de Vries, J.H.; Ocké, M.C.; Harttig, U.; Boeing, H.; Veer, P.V.T. Comparing four methods to estimate usual intake distributions. Eur. J. Clin. Nutr. 2011, 65, S92-S101. [CrossRef] 